\title{
First Account of the Yellow-bellied Slider (Trachemys scripta scripta) in Texas
}

Eric C. Munscher ${ }^{1}$, Stephen G. Ross ${ }^{1}$, Chris Havel ${ }^{2}$, L.K. Wolfe III ${ }^{1}$, Chris Collins ${ }^{1}$, and Roxanne A. Losey ${ }^{3}$

${ }^{1}$ SWCA Environmental Consultants, 10245 West Little York Road Suite 600 Houston Texas 77040, USA (emunscher@swca.com, sross@swca.com, lkwolfe@swca.com,ccollins@swca.com)

${ }^{2}$ Seaworld San Antonio, 10500 SeaWorld Drive, San Antonio, Texas, 78251, USA (chris.havel@seaworld.com)

${ }^{3}$ Disney’s Animal Kingdom, 551 N Rainforest Rd, Lake Buena Vista, Florida 32830. USA (rlosey@aol.com)

Photographs by L.K. Wolfe III

$\mathrm{O}$ n 16 April 2013, during annual turtle population sampling at Comal Springs (Landa Lake) in New Braunfels, Texas $\left(29.714917^{\circ} \mathrm{N},-98.135292^{\circ} \mathrm{W}\right.$, Datum WGS84), the authors collected and identified an adult male (CL 166 $\mathrm{mm}$ ) Yellow-bellied Slider (Trachemys scripta scripta; Fig. 1).

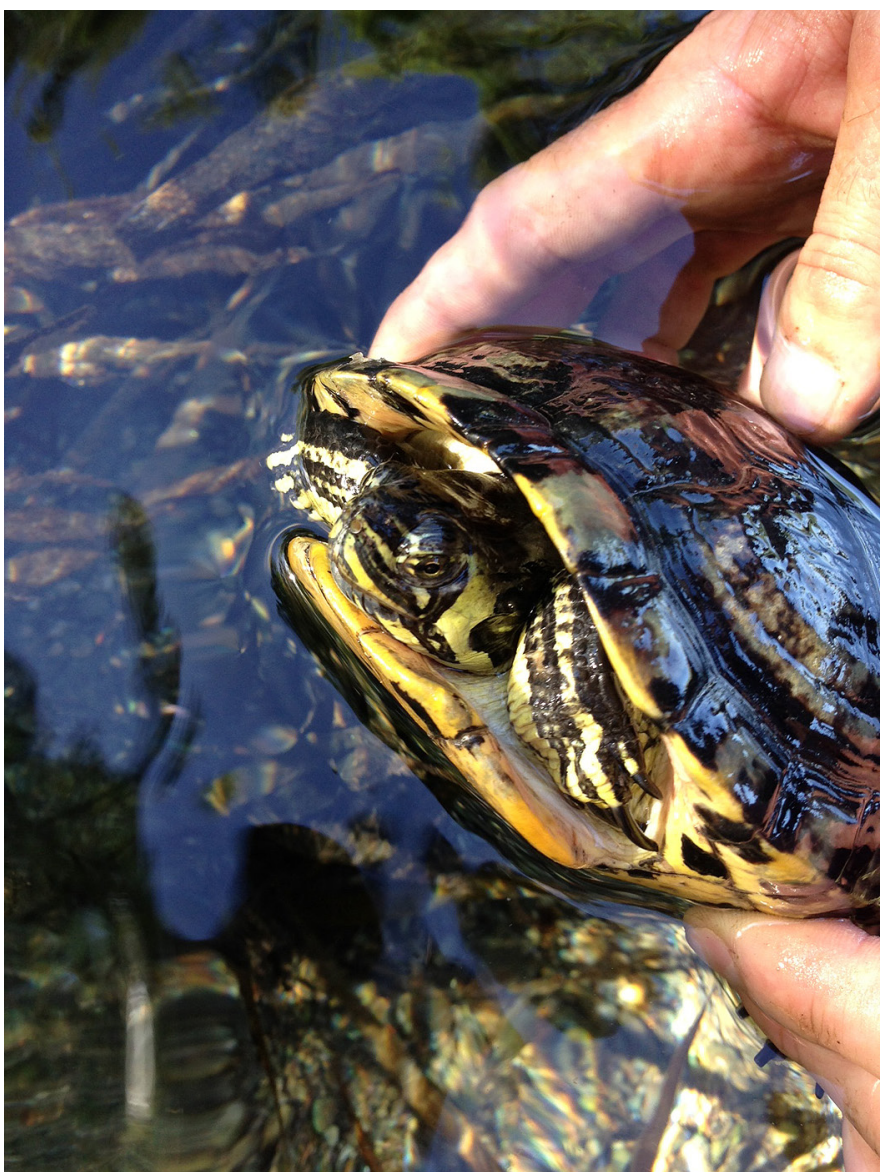

This turtle was caught by hand while snorkeling the northern escarpment side of Landa Lake, the headwaters of the Comal River. Photographs of the specimen were sent to the Amphibian and Reptile Diversity Research Center at the University of Texas at Arlington (UTA DC \#s 8054-8056),

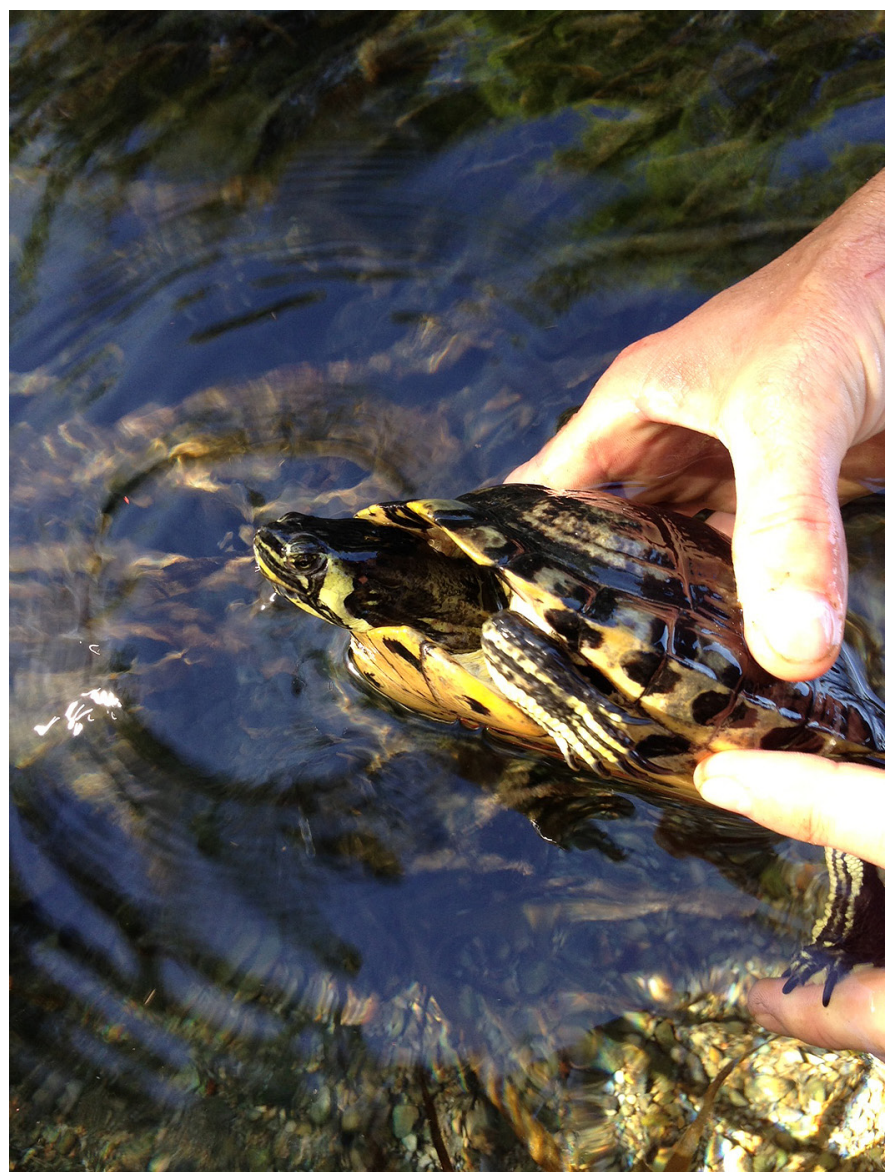

Fig. 1. An adult male Yellow-bellied Slider (Trachemys scripta scripta; UF 168594) captured during the 2013 spring sampling session of a long-term monitoring program at Comal Springs (Landa Park), New Braunfels, Texas. Note the yellow cheek patch characteristic of this taxon. 

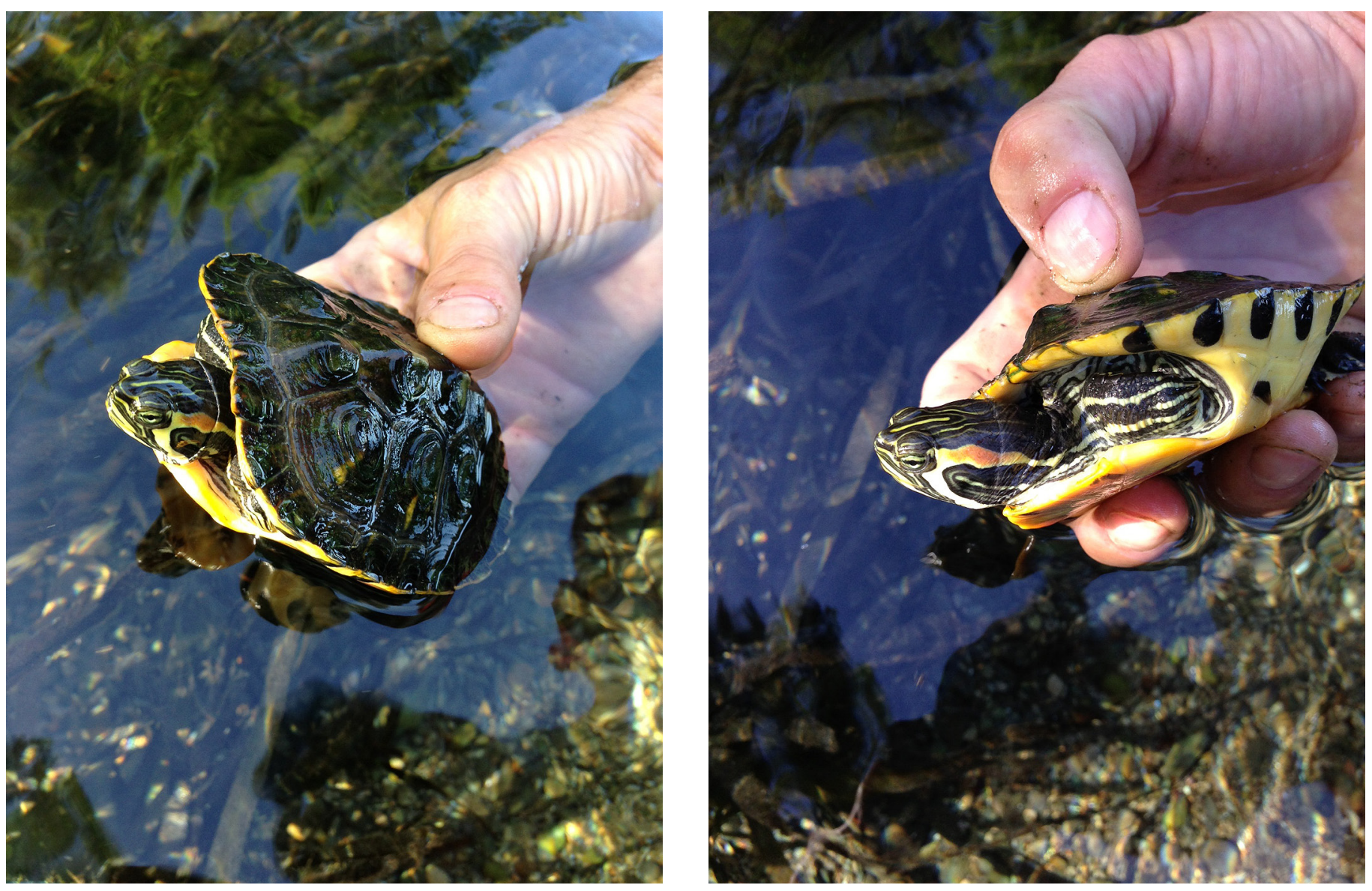

Fig. 2. Possible hybrid between native Red-eared and introduced Yellow-bellied Sliders (Trachemys scripta elegans $\mathrm{x}$ T. s. scripta) showing characteristics of both subspecies. This turtle was captured during the 2013 spring sampling session of a long-term monitoring program at Comal Springs (Landa Park), New Braunfels, Texas.

where Dr. Carl J. Franklin, based on key morphological characteristics that differ substantially from those of the Redeared Slider (T. s. elegans) (e.g., Conant and Collins 1991, Buhlmann et al. 2008), identified this turtle as a Yellowbellied Slider.

This subspecies has never been reported from Texas. Our photographic vouchers represent not only a Comal County record (Dixon 2000, 2012) but a new record for the state of Texas (Dixon 2000, 2012). Several other turtles captured during the first year of sampling at Comal Springs also had characteristics of Yellow-bellied Sliders that included large yellow cheek patches and black plastral mottling (Fig. 2). We believe that these individuals might be intergrades between Yellow-bellied and Red-eared Sliders.

Many turtle species, including Red-eared Sliders, Yellowbellied Sliders, and Mississippi Map Turtles (Graptemys pseudogeographica kohnii), have been widely sold throughout the country by the pet industry (Krysko et al. 2011). Although Yellow-bellied Sliders currently are not abundant in the Texas pet trade, we believe that the voucher specimen is most likely a "pet turtle" drop off, wherein a young turtle was purchased and the owner subsequently released it into a local waterway. This individual's relatively small size (presumably reflecting a young age class) suggests that this turtle had recently been released at the park. Rose et al. (1998) reported a similar situation in a nearby locality by documenting the introduction of Florida Red-bellied Cooters (Pseudemys nelsoni) in Hays County, Texas.

Invasive species have been a major issue in Florida for many years (Krysko et al. 2011). Although Texas has fewer invasive species than Florida, species like the Yellow-bellied Slider can pose serious ecological issues. Introduced sliders could compete with native species or, as suggested by the presence of putative hybrids, compromise the genetic integrity of native Red-eared Sliders through interbreeding.

\section{Acknowledgements}

We thank the SWCA Environmental consultants for supporting the research crew during the sampling at Comal Springs as well as current and past North American Freshwater Turtle Research Group (NAFTRG) volunteers, who have facilitated this long-term study over the past 14 years. 


\section{Literature Cited}

Buhlmann, K, T. Tuberville, and W. Gibbons. 2008. Turtles of the Southeast. University of Georgia Press. Athens.

Conant, R. and J.T. Collins. 1991. A Field Guide to Reptiles and Amphibians, Eastern and Central North America. $3^{\text {rd }}$ ed. Houghton Mifflin Company, Boston, Massachusetts.

Dixon, J.R. 2000. Amphibians and Reptiles of Texas. 2nd ed. Texas A\&M University Press, College Station.
Dixon, J.R. 2013. Amphibians and Reptiles of Texas with Keys, Taxonomic Synopses, Bibliography, and Distribution Maps. 3rd ed. Texas A\&M University Press, College Station.

Krysko, K.L., K.M. Enge, and P.E. Moler. 2011. Atlas of Amphibians and Reptiles in Florida. Final Report, Project Agreement 08013. Florida Fish and Wildlife Conservation Commission, Tallahassee.

Rose, F.L., R.W. Manning, T.R. Simpson, and S. Jenkins. 1998. A sustaining population of the Florida Red-bellied Turtle, Psendemys nelsoni (Reptilia: Emydidae) in Spring Lake, Hays County, Texas. Texas Journal Science 50:89-92. 